\title{
Effect of Different Surface Treatments on The Tensile Bond Strength Between Acrylic Resin Teeth and Denture Base Material
}

\author{
Ihab Nafea Yaseen
}

BSc, M.Sc Dental Technology - Lecturer Department of prosthetic dentistry, College of Health and Medical Technology /Iraq - Baghdad

\section{ABSTRACT}

Aims of study: A study was carried out to assess the tensile bond strength between acrylic denture base and denture teeth after manipulation with different surface treatments. Methods: Thirty central incisors from acrylic denture teeth were cut at the neck (ridge lap surface). Such teeth were then allocated into three groups of different surface treatments: teeth in the first group received no further treatment; teeth in the second group were surface treated with a groove placed and reinforced with a metal wire; teeth in the third group were reinforced with a glass fiber. Each group was processed by water - bath. Results: The results showed that all treated groups improved the tensile bond strength was in a significant, level at $(P<0.01)$, while the third group glass fiber was the highest mean values. Conclusions: The metal wire enhanced significantly the tensile bond strength. The addition of glass fiber can significantly enhance the tensile bond strength between acrylic denture base and denture teeth.

\section{KEY WORDS}

Acrylic resin, Acrylic teeth, glass fiber, Tensile strength.

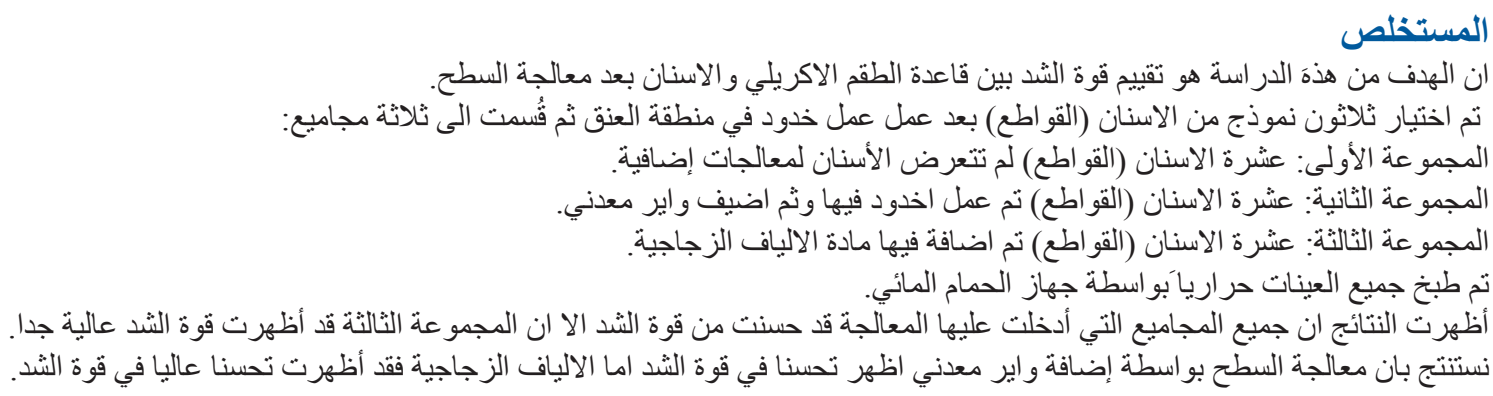

\section{INTRODUCTION}

Acrylic resins are the most commonly restorative materials used to make removable complete and partial dentures. Such materials to be polymerized require the activation of an initiator, such as benzoyl peroxide, to free radicals, in an addition polymer. The heat is usually generated either in a hot water bath or by micro waves ${ }^{(1)}$. The most commonly method used to process poly (methyl methacrylate) resin is the water bath ${ }^{(2,3)}$.

Plastic denture teeth are often preferred over porcelain teeth as they are easier to adjust and chemically bond to the denture base materials. Heatcured acrylic resins are the materials of choice for denture bases ${ }^{(4,5)}$. The failure rate of acrylic resin dentures due to the fracture has been reported to be an acceptable high ${ }^{(6)}$. The most common type of failure encountered was de-bonding or fracture of the teeth (7). The lack of adequate bonding at the tooth - base interface was due to:

a.Contamination of the surface, particularly by wax and possibly by sodium alginate mold seal.

b. The difference in the structure of the components due to their different processing routes ${ }^{(\boldsymbol{8})}$.

The failure of the bond between acrylic resin teeth and denture base material remains a significant problem. The literature indicated that the chemical and mechanical surface treatments of the denture tooth surface prior to bonding have enhanced the bond strength ${ }^{(9)}$. The current study was aimed to evaluate the effect of different surface treatments (reinforced metal and glass fiber) on the tensile bond strength between acrylic teeth and acrylic resin denture base material.

\section{METHODS:}

\section{Grouping of the specimens:}

Thirty teeth from acrylic resin were selected and all located into three different surface treatment groups as follow:

1.First group (10 samples): the teeth did not receive any treatment.

2.Second group (10 samples): the teeth were surface treated with a groove preparation and reinforced with a metal wire (Pigeon dental, Dentirak) .

3.Third group (10 samples): the teeth were surface treated with monomer and reinforced with glass fiber (Vetrotex -ocv reinforced, mouldingLtd.,UK)

\section{Preparation of specimens:}

Preparations of teeth:

Thirty central incisors were selected and were cut at the neck (gingival portion) as follow:

A rubber mold-casting ring was used to prepare (round form) stone bases. According to the manufactures instructions, dental stone was mixed and poured in the rubber mold. Approximately $4 \mathrm{~mm}$ of the incisor portion of each central incisor was embedded in the stone mixture in such way that the gingival 
portion of the tooth portion of the tooth parallel to the horizontal plane ${ }^{(10)}$. The stone bases with teeth were fixed on surveyor table by the screw. A grasping unit was designed and prepared for this study for holding a portable engine hand piece in a fixed position (parallel to the vertical arm and perpendicular to the surveyor table) and allowed horizontal movement of the hand piece with surveyor arm. The surveyor arm allowed also a vertical movement of the hand piece. By this a groove was placed on the tooth neck surface. A portable engine hand piece waxed fixed on the surveyor arm, and with constant speed (4000rpm) was used for cutting by using at a stone disk bur for each tooth and in one-way direction to the ridge lap portion of each tooth was cut.

\section{Mold preparation:}

A wax mould made form rectangular shape, dimensions of $(17 \mathrm{~mm}, 10 \mathrm{~mm}, 7 \mathrm{~mm}, 9 \mathrm{~mm}, 3 \mathrm{~mm}){ }^{(5)}$ as shown in the figure (1).

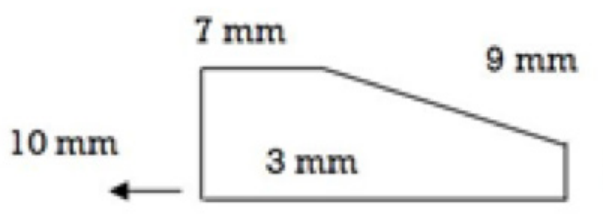

$3 \mathrm{~mm}$

\section{$17 \mathrm{~mm}$}

Figure (1): Wax mould for a rectangular wax block.

The teeth were waxed on the beveled surface of a rectangular wax block. The slope of the beveled surface aligned each denture tooth so that the long axis of the tooth was at (45) degree from the base of the wax block, figures (2 and 3).

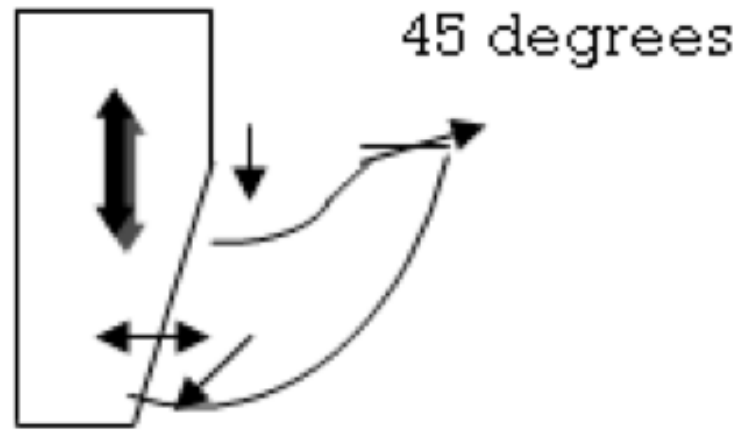

Figure (2): Slope of the beveled surface aligned each denture tooth.

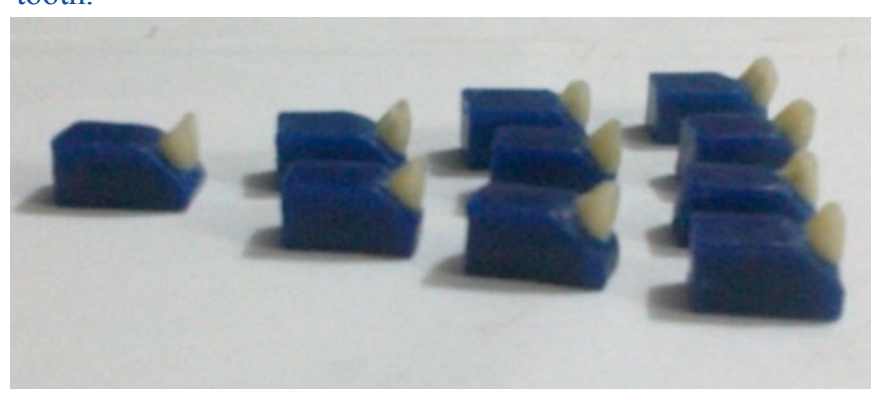

Figure (3): Specimens (after fixed each tooth).

\section{Addition of fiberglass}

Electronic balance was utilized to weigh the amount of fibers that used in this study. Short fibers (0.375 grams) were added randomly to the acrylic powder and mixed together. The acrylic monomer was then added to the powder and mixed using cement spatula. When the mixture reached a dough stage. The acrylic was packed within the stone mould, cured and finished ${ }^{(11)}$.

\section{Addition of reinforced metal wire}

Ten acrylic maxillary central incisors were selected and cut at the neck (gingival portion) using fissure bur for each tooth and in one-way direction to the ridge lap portion. Next, a stainless steel wire of $(9 \mathrm{~mm})$ diameter and $(6 \mathrm{~mm})$ length was selected. A half of wire length was fixed in tooth groove via adhesive material and the rest was embedded on wax pattern ${ }^{(12)}$.

The conventional flasking technique for complete denture was followed in the mold preparation as previously described. The lower half of the flask was completely filled with dental stone, which mixed according to manufacture instruction $(100 \mathrm{gm} / 31 \mathrm{~mL})$, $(\mathrm{p} / \mathrm{w})$. The wax patterns were then inserted to one half of its depth (figure 4). The stone and wax pattern were lubricated with separating medium and allowed to dry. The upper half of the flask was placed over the lower half and then filled with stone. The mould was left to set for (60 min.) before mixing to the next step.

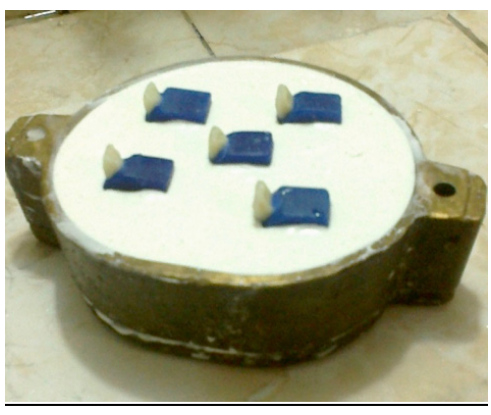

Figure (4): The wax pattern when insert in stone.

Pink heat cure acrylic powder with liquid was mixed according to manufactures instruction $(3 \mathrm{gm} / 1 \mathrm{ml})(\mathrm{p} / \mathrm{L})$. The teeth were properly positioned within the mould. When the mixture reached a dough stage, the acrylic dough was then placed inside the mould. The two halves of the flask were finally closed under pressure until metal to metal contact had been established and left under press (20 bar) for $\left(5 \mathrm{~min}\right.$.) ${ }^{(13)}$. The curing was done in a thermostatically controlled water bath (temperature at $\left(74^{\circ} \mathrm{C}\right)$ for $\left(2^{1 / 2}\right.$ hour) then in $\left(100^{\circ} \mathrm{C}\right)$ for $1 / 2$ hour ${ }^{(14)}$. Heat source was then switch on and left for (90 min.) and then boiled for (30 min.). After that, the flask was allowed to cool down in the water bath ${ }^{(15)}$. Once curing, the specimens were 
removed carefully from the stone mould. The samples were then finished and polished ${ }^{(16)}$ figure (5). Before testing, all specimens were stored in distilled water $\left(37^{\circ} \mathrm{C}\right)$ in 10 days ${ }^{(5)}$.

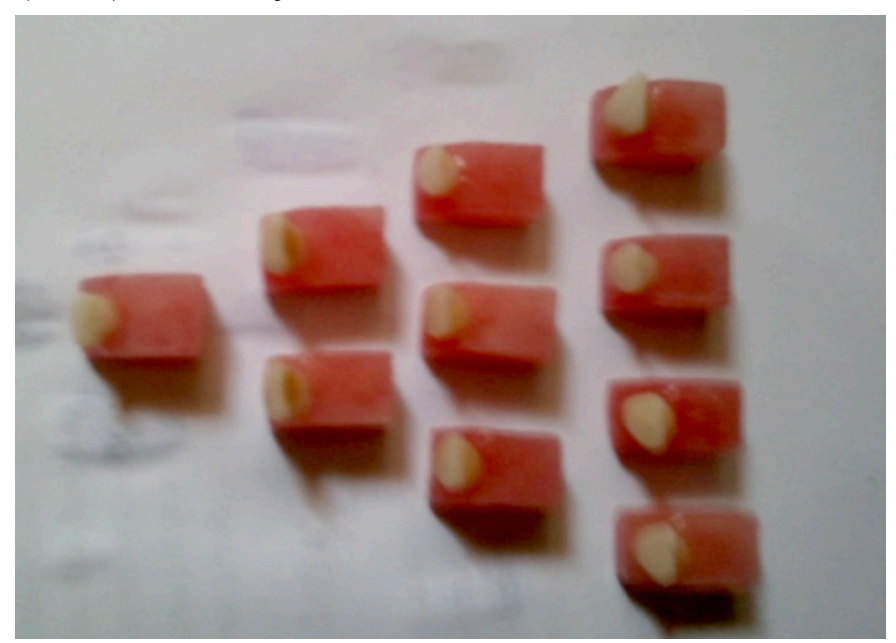

Figure (5): specimens after finishing and polishing

\section{Tensile Bond Strength Test:}

All specimens were tested in the same day. The specimens were hold in metal fixture (grasping unit). The metal fixture was firmly hold to an instron universal testing machine model 1195 (Instron, corporation, canton mass). The compressive load was applied with a loading testing machine at (45) degrees from the long axis of each denture tooth on the palatal surface (figure 6). Tensile bond strength test was then performed using a $(200 \mathrm{~kg})$ load cell with a cross head speed $0.5 \mathrm{~mm} / \mathrm{min}$ with a chart speed $(20 \mathrm{~mm} / \mathrm{min}$. $)$. Specimens were loaded until fracture. The data was recorded in kilograms. The tensile bond strength was calculated according to the formula below: -

\section{$\mathrm{T} . \mathrm{S}=\frac{\mathrm{F}}{\mathrm{S}}$}

$\mathbf{S}=\frac{\pi 2}{4} X D$

where $\pi=\frac{22}{7}$

$\mathrm{D}$ (diameter) $\stackrel{7}{=} 5 \mathrm{~mm}, \mathrm{~S}=19.64 \mathrm{~mm}^{2}$

$\mathrm{TS}=$ tensile strength $\left(\mathrm{N} / \mathrm{mm}^{2}\right)$

$\mathrm{F}=$ Force at failure $(\mathrm{N})$.

$\mathrm{S}=$ area of cross section ${ }^{(17)}$.

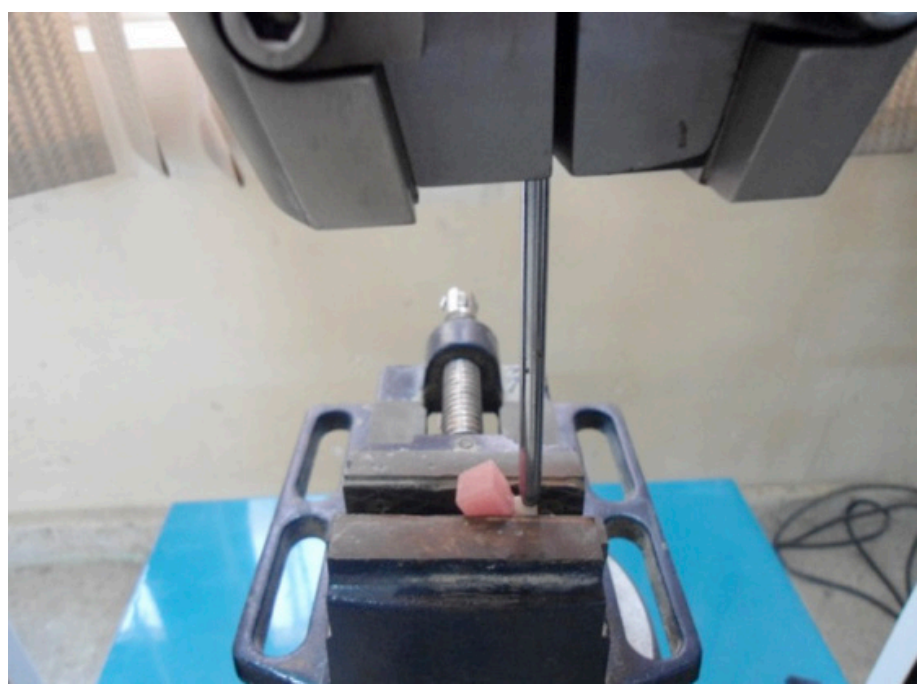

Figure (6): specimen with chucks in place ready for test.

\section{RESULTS}

All values of tensile bond strength were shown in the Table (1).

The table (1) and figure (7) showed that the specimens which were not surface treated had a low tensile bond strength $\left(0.19 \mathrm{~N} / \mathrm{mm}^{2}\right)$. Furthermore, the specimens which treated with reinforced metal wire had a mean value $\left(0.23 \mathrm{~N} / \mathrm{mm}^{2}\right)$.

Moreover, the specimens reinforced with glass fiber were the highest tensile bond strength value $\left(0.26 \mathrm{~N} / \mathrm{mm}^{2}\right)$.

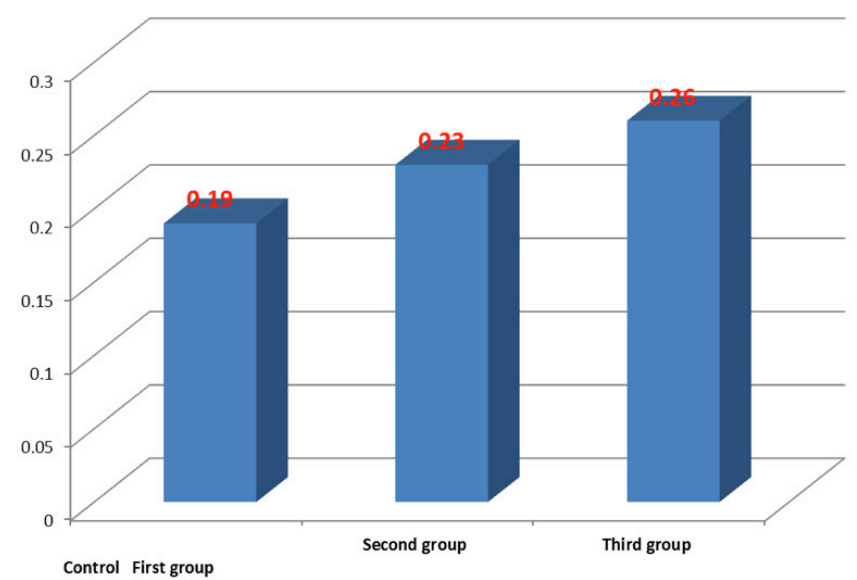

Figure(7): Disgram showing the distribution oftensile bond strength among studies groups.

Table (1): Descriptive statistics of mean distribution of tensile bond strength among studies groups.

\begin{tabular}{|c|c|c|c|c|c|}
\hline Studies groups & Mean $\left(\mathbf{N} / \mathbf{m m}^{2}\right)$ & $\begin{array}{c}\text { Standard devi- } \\
\text { ation }\end{array}$ & $\begin{array}{c}\text { Stander } \\
\text { error }\end{array}$ & Minimum & Maximum \\
\hline First group (Control) & 0.19 & 0.021 & 0.006 & 0.16 & 0.22 \\
\hline Second group & 0.23 & 0.0205 & 0.0065 & 0.21 & 0.26 \\
\hline Third group & 0.26 & 0.0188 & 0.0059 & 0.24 & 0.29 \\
\hline
\end{tabular}

The results demonstrated that there were studied groups as shown in tables 1, 2, and 3 . The statistically significant differences between the ANOVA test indicated that there were highly 
significant differences between all groups as shown in table 2.

Table (2): ANOVA test between groups tensile bond strength among studies groups.

\begin{tabular}{|c|c|c|c|}
\hline & $\boldsymbol{F}$-test & $\boldsymbol{P}$-value & Sig \\
\hline $\begin{array}{c}\text { Between } \\
\text { groups }\end{array}$ & 29.73 & $\mathrm{P}<0.01$ & HS \\
\hline
\end{tabular}

Table (3): Least significant difference (LSD) test for tensile bond strength among studies groups

\begin{tabular}{|c|c|c|c|}
\hline \multicolumn{4}{|c|}{ (LSD) test } \\
\hline $\begin{array}{c}\text { Studies } \\
\text { groups }\end{array}$ & $\begin{array}{c}\text { First } \\
\text { group }\end{array}$ & $\begin{array}{c}\text { Second } \\
\text { group }\end{array}$ & Third group \\
\hline First group & - & HS & HS \\
\hline Second group & & - & $-\mathrm{S}$ \\
\hline Third group & & & - \\
\hline
\end{tabular}

\section{DISCUSSION}

Many studies have been carried out to assess and improve the bond strength of acrylic teeth to denture base material. Bond strength can be affected by several factors, including cross linking of the materials, availability of the monomer, and the degree of contamination during processing. Several procedures for repairing acrylic dentures are employed by Japanese dental laboratories, to repair using wrought wire. The denture is prepared by cutting groove at the broken area. The groove should made slightly wider than the wrought wire and deep enough so that the wire can completely seated in the groove and fixed in it. The joint design is important in this process to success of the repair ${ }^{(18,19)}$.

In this study, the bond strength between acrylic resin teeth and denture base resins were evaluated in tension. Results showed that the most of tensile bond strengths are a mostly around or less than that determined by denture teeth. This is best explained by the differences in the experimental design. The result of this study showed the tensile bond strength of acrylic teeth, as a function of different reinforcement to denture base resin was significantly at ( $\mathrm{P}$ value $<0.05$ ). This result is in agreement with Takahashi et al. and others ${ }^{(5,20 \& 21)}$. While our results disagree with Geert \& Jooste and others ${ }^{(22,23 \& 24)}$. A possible explanation for such differences in the results is the difference in the experimental design. The previous studies applied compression load at (45) degrees to the palatal surface of a denture tooth mounted on a rectangular resin block (thickness was not mentioned). In this study teeth after cutting were allocated into three groups previously mentioned, the first group (control) were the teeth were not surface treated, in the $2^{\text {nd }}$ group the teeth were treated with groove and reinforced with a metal wire, in the $3^{\text {rd }}$ group the teeth were conditioned with monomer with addition of reinforced glass fiber. The results showed that all surface treatments had significant difference at $\left(\mathrm{p}_{\text {value }}<0.05\right)$, except the control are non-significant difference at $\left(\mathrm{P}_{\text {value }}>0.05\right)$ in improving tensile bond strength mean value as shown in table $(2,3$, and 4$)$. This is agreement with Takahashi et al., and others ${ }^{(5,21, ~ \& 25)}$.

The results of the current study revealed that there were significant differences among the tested groups. The groups reinforced with a metal wire has a higher mean value of tensile bond strength than untreated group. This may be due to adding of reinforced metal wire give support to the bond between acrylic teeth and acrylic resin denture base and give it higher tendency and stability to withstand a higher tensile bond strength. This study agreed with Polyzios et al., (12) and Suzuki (26).

In addition, the samples that were surface treated by addition of glass fiber had higher mean values of tensile bond strength when compared with control group. This can be partly explained by the presence of glass fiber in resin ensures transferring of load from matrix to fiber. This will lead to an increase in the strength of the resin and allows the resin tolerate the force of tension more than the samples that had no fiber in their structure. Adequate quantity of fiber present in resin can increase the acrylic strength. This is in agreement with Ehasn ${ }^{(11)}$, and disagree with Polyzios et al., ${ }^{(12)}$.

\section{CONCLUSIONS:}

The following conclusions can be drawn:

1. A higher bond strength of acrylic denture base to the acrylic teeth was obtained with metal wire as compared to untreated group.

2. The addition of glass fiber can enhance the tensile bond strength.

\section{REFERENCES}

1. Kimura H, Teraoka F, and Sugita M. Applications of microwave for denture technique. (Part 3): Development of model materials for microwave polymerization. J. Osaka. Univ. Dent. Sch. 1987; 27: 41-50.

2. Phillips RW. Skinners science of dental material. $8^{\text {th }}$ ed. Philadelphia. WB Saunders Co., 1982; Chap. 12, pp. 42-58.

3. Craig RG. Restorative Dental Materials. $7^{\text {th }}$ ed.Louis. The C.V. Mosby Co. 1985; PP133-142,458-484,498-501.

4. Craig RG,O'Brien WJ, and Powers JM.. Dental Materials, properties and manipulation. $6^{\text {th }}$ ed.Louis .The C. V. Mosby Co. 1996;PP242-264.

5. Takahashi Y, Chai J, Takahashi T, and Habu T. Bond strength of denture teeth to denture base resins. Int. J. Prosthodont: 
2000;13(1):59-65.

6. Cunningham JL. Bond strength of denture teeth to acrylic base. J. Dent. 1993; 21:274-280.

7. Aljudy HJ., Hussein ANA, and Safi IN. Effect of surface treatments \&thermo cycling on shear bond strength of various artificial teeth with different denture base materials .J Bagh Coll Dentistry ,2013;25(1):5-13

8. Cunningham JL, and Benington IC. A survey of the prebonding preparation of denture teeth and the efficiency for dewaxing methods. J. Dent 1997; 25 (2): 125 - 128.

9. Cunningham JL. Shear bond strength of resin teeth to heat cured and light cured denture base resin. J oral Rehab, 2000; 27:312-316. (www.ivsl.org).

10. Cunningham JL, and Benington IC. Anew technique for determining the denture tooth bond. J. oral. Rehabil. 1996; 23(3):202-209.

11. Ehsan A. The effect of fiber reinforcement on some properties of repaired acrylic resin with different joint shape preparation. Thesis College of Dentistry University of Baghdad, 2005.

12. Polyzios GL, Tarantili PA, Farngou MJ and Andreopoulos AG. Fracture force, deflection at fracture, and toughness of repaired denture resin subjected to microwave polymerization or reinforced with wire metal or glass fiber. J Prosthet Dent, 2001; 86(6):613-619.

13. Abdul - Karim JF. Evaluation of some technical properties of acrylic denture base material relined with different denture relines materials. M.Sc. Thesis College of Dentistry University of Baghdad, 2001.

14. Abdulrazzaq H.T. The effect of glass flakes reinforcement on some mechanical properties of heat - cured poly (methyl methacrylate) denture base materials . M.Sc. Thesis College of Dentistry University of Baghdad, 2013.

15. Craig R.G., Power JM. Restorative dental materials. $11^{\text {th }}$ ed .St. Louis :Mosby Co. 2002; Chapter (21) 636-656).

16. Abdul - Rahmann BA. Evaluation of water sorption, solubility, and bond strength of some soft lining materials. M.Sc. Thesis College of Dentistry University of Baghdad, 2002.

17. Vergani CE, Machaclo Al ,Giampaolo ET, and Pavarina AC. Effect of surface treatment on bond strength between composite resin and acrylic resin denture teeth. Int. J. prosthodont, 2000;13(5):383-386.

18. Azad AA, Siddiqui AZ, Jawad A., Zia M,\& Ali T. Effect of mechanical modification of acrylic resin denture teeth bonded to acrylic denture base .Pakistan oral \& dental Journal ,2012;32(1);149-153.

19. Nomoto R, Takayama. Repair strength denture base resin using various procedure. J Prosthetic dent. 2010;25(2):120125.

20. Schneider R1, Curtis ER, and Clancy JMS. Tensile bond strength of acrylic resin denture teeth to a microwave or heat processed denture base. J. Prosth. Dent. 2002;88(2):145150.

21. Abu-Anzeh RH. Evaluation of tensile bond strength of tooth denture base resin as a function at different surface treatments and processing regimes. M.Sc. Thesis, College of Dentistry, University of Baghdad, 2003.

22. Geerts GA, Jooste $\mathrm{CH}$. A comparison of the bond strengths of microwave- and water bath-cured denture material.. J Prosthet Dent. 1993 Nov;70(5):406-9.

23. Buyukyilmaz S, and Ruyter I.E. The effects of polymerization temperature on acrylic resin denture base tooth bond. Int. J.
Prosthodont, 1997;10(1):49-54.

24. Hasan RH. Denture teeth bond strength to heat water bath and microwave cured acrylic denture base materials. A comparative study M.Sc. Thesis, College of Dentistry, Mosul University, 2002.

25. Cardash HS, Applebaum B, Baharav H, and Librman R. The effect of retention grooves on tooth-denture base bond. J. Prosth. Dent. 1990; 64(4):492-496.

26. Suzuki S. Bonding of denture base resin to plastic denture teeth by metal wire. J. Biomed Mater Res. 2000. 